\title{
Walter Goebel and Saskia Schabio, eds., Locating Postcolonial Narrative Genres
}

\section{Cécile Girardin}

\section{(2) OpenEdition \\ 1 Journals}

Electronic version

URL: https://journals.openedition.org/ces/5833

DOI: $10.4000 /$ ces.5833

ISSN: 2534-6695

Publisher

SEPC (Société d'études des pays du Commonwealth)

\section{Printed version}

Date of publication: 1 September 2013

Number of pages: 105-107

ISSN: 2270-0633

\section{Electronic reference}

Cécile Girardin, "Walter Goebel and Saskia Schabio, eds., Locating Postcolonial Narrative Genres", Commonwealth Essays and Studies [Online], 36.1 | 2013, Online since 16 April 2021, connection on 22 July 2021. URL: http://journals.openedition.org/ces/5833 ; DOI: https://doi.org/10.4000/ces.5833

This text was automatically generated on 22 July 2021.

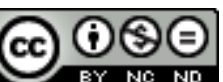

Commonwealth Essays and Studies is licensed under a Licence Creative Commons Attribution - Pas d'Utilisation Commerciale - Pas de Modification 4.0 International. 


\title{
Walter Goebel and Saskia Schabio, eds., Locating Postcolonial Narrative Genres
}

\author{
Cécile Girardin
}

\section{REFERENCES}

Walter Goebel and Saskia Schabio, eds. Locating Postcolonial Narrative Genres. London:

Routledge, 2013. 222 pp. ISBN (hb): $9870415539609 . £ 80$

Locating Postcolonial Narrative Genres brings together the contributions of a 2009 conference that took place at the University of Stuttgart, "to find out how postcolonial texts have determined the evolution or emergence of specific formal innovations in narrative genres" (1). In other words, this study investigates how narrative genres have been transformed by the advent of a specifically "postcolonial" aesthetics. Moving slightly away from the political, the volume nonetheless remains anchored in the tradition of postcolonial scholarship as it has been widely practiced since the 1990s, by addressing the following questions: why write according to the generic templates of the imperial power? How does one write "back" and adopt Western literary genres? Do literary genres, after all, call for a universal reading? Is there not a tradition preexisting the one imposed by the imperial power? In their introduction, the editors delineate the contributors' common endeavor to "decenter Western aesthetics" (2) or to accomplish "aesthetic decolonization" (3) made necessary by the "predominance of Western aesthetics and its terminology" (2).

2 The originality and boldness of the volume lie in the combination of its loose definition of postcolonial writing and its strong commitment to local practices - a combination that prevents sweeping generalizations. The texts under scrutiny range from the early decolonizing period to the contemporary one, and cover every continent (Australia, India, the Caribbean, Africa) with the exception of Canada. They also include areas less 
often featured in postcolonial studies, such as Palestine and Egypt. This choice of corpus, added to the study of one of the broadest and most complex questions in literary criticism (narrative genres), at times makes for a diversified volume. Consider, for instance, the collision of notions such as reconciliation in Australia, marriage and love in India, Gandhian utopia or crime fiction in contemporary Africa.

The book is divided into four parts: the first one ("Pre- and Post-colonial Aesthetic Templates") considers pre-colonial and utopian aesthetics as proof of the existence of postcolonial genres located outside of the Western narrative genre paradigm, be it Indian storytelling (Trivedi), Gandhian utopia (Ashcroft) or Glissantian poetics (Schabio). Part II, "Resistant and Subversive Genres," examines the various ways in which postcolonial narratives respond to Western forms, such as the epic (Williams), European realism (Msiska), crime fiction (Deckard) or the autobiography (Goebel), by subverting and transcending them. Part III ("Longue Durée Perspectives and Orature") specifically discusses the evolution of oral forms as literature: the premises of the chapters rely on the idea that indigenous forms such as folktales (Ghazoul), legends (El Kholy) and stories transmitted orally (Wieman) provide a shield against the hegemony of the written text, and ultimately against globalization. Part IV, "Emerging Narrative Genres," offers insight into what the authors see as the emerging genres of the postcolonial field: the "Sorry novel" (Kossew), "translational fiction" (Hamdy), the short story (Brosch) and nostalgic discourse (Banita).

The book is most stimulating when the issue of narrative genre is confronted with that of universal values, and the best chapters accommodate a reflection on established genres, such as the epic and the autobiography, and on what it means to be postcolonial. Patrick Williams, in his study of Mahmoud Darwich's poetry, demonstrates that the Palestinian poet succeeds in endowing the epic form with political and contemporary content while preserving its fundamental purpose, which is to "articulate his people's story" (74). It is "non-nationalist, non-heroic, nontriumphalist" (71), thus defying the Bakhtinian definition of the epic. On the contrary, his poetry consists in "novelizing" and historicizing the epic, by making it a "poetry of Troy" (68), that is to say, a poetry of the defeated. Similarly, Walter Goebel shows how Naipaul revolutionized the autobiography, a genre inherited from the Enlightenment, by denying it closure and coherence, using third-person narrators, multiplying alter egos, fragmenting his texts. His notion of "melancholy heterobiographical form" best describes Naipaul's unique life-writing project, which inevitably places the critic in a conundrum whenever $\mathrm{s} / \mathrm{he}$ attempts a generic categorization. The other essays dealing with genre subversion unfortunately tend to rely on less original scholarship, either resorting to hybridity theory or dwelling on the markers of orality and traditional storytelling within contemporary texts. Some of them, however, successfully cover unchartered territory, such as the studies on Mabanckou's African Psycho (Deckard) or on Dasgupta's Tokyo Cancelled (Wieman), which deserve to be cited for their effort to combine postcolonial studies with globalization and postmodern thought. The merit of this volume is to point at the plasticity of age-old generic codes and at the ability of great writers to inhabit such codes and to make them relevant to the here and now. As a case in point, the chapter devoted to the "Sorry novel" of contemporary Australia as an emerging genre (Kossew) calls for comparative work in many other areas of the postcolonial world also affected by issues of apology, reconciliation, and reparation. 
Such potential for theorization on a global level would have deserved to be voiced more explicitly.

Indeed, the main pitfall of the book lies in its failure to fully assess the universal quality underpinning the longevity of, say, the epic or the novel. Instead, the volume is too often penetrated by a fierce desire to break away from Western narrative genres viewed as imported models for representing reality, in particular from the novel and from what the authors call "novelism" - that is to say, the dogmatic assumption of the hegemony of the novel in literature, a trend that goes hand in hand with imperialism itself. This is made clear in Harish Trivedi's opening essay, which refutes the idea according to which the novel, in particular the Victorian novel, was "imported" to India. According to him, there is a specific Indian realism, epitomized by the representation of love, marriage and the extended family, in the works of many authors writing in the vernacular languages. He proceeds to comment on stories where marriage does not come at the end, as is usually practiced in Western stories, but at the beginning of narratives, allowing for a thorough - and supposedly more authentic depiction of "real life" after marriage. He also underlines a strong preference for the short form in India, which comes as a counterpoint to the "miscegenation between Western form and Indian reality" (19). Therefore, he consistently places his study out of the Western paradigms of closure, progress, individualism and the Enlightenment, which he considers inadequate to address Indian concerns. Similarly, in his chapter on utopia, Bill Ashcroft posits that the doxa inherited from Benedict Anderson of the parallel rise of novel and nationalism, needs to be radically challenged. To do that, he promotes the Gandhian model, with its anti-Enlightenment, anti-progress, antiWestern, anti-imperialist undercurrents, as able to foster the necessary utopian ideals to craft an Indian imagined community. The problem with such forceful arguments lies not in the proposals themselves, which are quite relevant (like the need to reappraise the short story or folktales in specific postcolonial contexts), but in the violent refusal to view literary genres, and most notably the novel, as flexible, open, and likely to be revisited, questioned, reinvented, and taken forward thanks to experimentations with tradition.

6 Goebel and Schabio's study, although bold in its ambition to place aesthetics back on the center stage, is unfortunately limited in scope due to the defensiveness of some of the authors. By and large this resistance is a symptom of what postcolonial studies have experienced in some of its latest developments, in the difficulty to move beyond the "writing back" paradigm, and the impossibility of escaping binary oppositions, at a time when a supposed neocolonialism of the West has replaced colonialism.

\section{AUTHORS}

\section{CÉCILE GIRARDIN}

Cécile GIRARDIN is a lecturer at the University of Orléans. Her research focuses on postcolonial literature and theory, especially from South Asia. She has published numerous articles on the 
political dimension of contemporary literature in the works of Salman Rushdie, V. S. Naipaul, Anita Desai, Kiran Desai, Hari Kunzru, Mohsin Hamid and Amitav Ghosh. 